IZA DP No. 8829

The Objective Measurement of World-Leading Research

Andrew J. Oswald

February 2015

Forschungsinstitut zur Zukunft der Arbeit Institute for the Study of Labor 


\title{
The Objective Measurement of World-Leading Research
}

\author{
Andrew J. Oswald \\ University of Warwick \\ and IZA
}

\author{
Discussion Paper No. 8829 \\ February 2015
}

\author{
IZA \\ P.O. Box 7240 \\ 53072 Bonn \\ Germany \\ Phone: +49-228-3894-0 \\ Fax: +49-228-3894-180 \\ E-mail: iza@iza.org
}

Any opinions expressed here are those of the author(s) and not those of IZA. Research published in this series may include views on policy, but the institute itself takes no institutional policy positions. The IZA research network is committed to the IZA Guiding Principles of Research Integrity.

The Institute for the Study of Labor (IZA) in Bonn is a local and virtual international research center and a place of communication between science, politics and business. IZA is an independent nonprofit organization supported by Deutsche Post Foundation. The center is associated with the University of Bonn and offers a stimulating research environment through its international network, workshops and conferences, data service, project support, research visits and doctoral program. IZA engages in (i) original and internationally competitive research in all fields of labor economics, (ii) development of policy concepts, and (iii) dissemination of research results and concepts to the interested public.

IZA Discussion Papers often represent preliminary work and are circulated to encourage discussion. Citation of such a paper should account for its provisional character. A revised version may be available directly from the author. 
IZA Discussion Paper No. 8829

February 2015

\section{ABSTRACT}

\section{The Objective Measurement of World-Leading Research ${ }^{\star}$}

How should the productivity of research universities be measured? This task is difficult but important. The recent Research Excellence Framework in the UK, which was based on peer review, suggests that there has been a marked improvement in UK academic research in economics and in many other subjects. But is it possible to design an objective check on, and measure of, a nation's 'world-leading research'? Following a variant of a method developed in Oswald (2010), I examine citations data on 450 genuinely world-leading journal articles over the Research Excellence Framework period 2008-2014. The UK produced 54 of these articles, namely, $12 \%$. This compares to 45 articles, namely $10 \%$, using the same methodology over the Research Assessment Exercise period 2001-2008. I conclude that it is possible to produce an objective measure of world-leading research, and that UK economics did show a small improvement.

JEL Classification: J0, D24, I23, J24, O32

Keywords: economics of science, evaluation, European economics, United Kingdom, peer-review, Research Excellence Framework (REF), citations, Research Assessment Exercise (RAE)

Corresponding author:

Andrew J. Oswald

Department of Economics

University of Warwick

Coventry CV4 7AL

United Kingdom

E-mail: andrew.oswald@warwick.ac.uk

\footnotetext{
* Peter Neary and Amanda Goodall gave me interesting suggestions. I thank also the CAGE centre and the ESRC for support.
} 
"4* - Quality that is world-leading in terms of originality, significance and rigour."

UK Research Assessment Exercise: REF 2014 www.ref.ac.uk

"My department refused to put me in for the REF, because one of my articles appeared in what they said was a 2* journal. Yet that article was more cited than the vast majority entered by my whole Department. The world has gone mad."

Private comment to me from an anonymous senior UK economics professor.

"What I really care about is how to get a top journal on to my CV. That is my ultimate goal." Private comment to me from a young UK economist.

\section{Introduction}

Governments across the world allocate billions of pounds to academic research and for that reason they must attempt to judge the quality of their universities. Methods for doing so, however, remain controversial. Critics of exercises such as the UK Research Excellence Framework worry about the use of peer-review, by predominantly UK scholars, as the dominant approach. A creative paper by Pierre Regibeau and Katherine Rockett [REGIBEAU and ROCKETT 2014] makes the remarkable point that a department consisting entirely of past Nobel Prize winners would not have performed better in a recent assessment exercise than two of the leading UK economics departments. The authors conclude that in some way the present procedures must be under-weighting the really influential kinds of scholarly output.

In a subject such as academic economics, is it possible to calculate objectively whether somewhere like the United Kingdom competes effectively in the production of major new ideas? The results of the RAE 2008 exercise, and the new REF 2014 exercise, suggest that the UK is strong in the subject of economics, and that, as in most parts of UK academia, the quality of UK economics is rising through time. The major departments had strikingly large proportions of their work assessed as $4^{\star}$, namely, as 'world-leading'. Five departments (UCL, LSE, Oxford, Cambridge, and Warwick) were rated in the REF as having produced $4^{*}$ research for more than $40 \%$ of their submitted articles and books. 
Is this believable and checkable? A related, and particularly important, concern is whether REF and RAE scores truly measure those iconoclastic papers that make a difference or instead simply capture highly competent professional solidity ${ }^{1}$. At the time of writing, as illustrated in the quotes above, there is an emphasis on journal labels as a criterion of quality (even though REF panels were formally forbidden from using such labels). However, there is much evidence that journal labels and journal impact factors are a poor sufficient-statistic for the quality of an individual article.

As one modern example, it may not yet be widely known that the most-cited research paper in 2009 in economics ${ }^{2}$ was published in the Oxford Bulletin of Economics and Statistics [ROODMAN 2009]. That paper's citations greatly exceed those to the single most-cited paper published in 2009 in journals with higher impact factors such as Econometrica, the American Economic Review, or the Review of Economic Studies. Related examples are given in SGROI and OSWALD [2013]. 3

When the problem is how to judge the quality of a country or a university department, it is likely, as argued in OSWALD [2013], that self-interest and subconscious biases will play a role. As academics we may suffer from -- and here I include myself -- the following biases:

(i) we may overestimate the importance of our own department;

(ii) we may overestimate the importance of our own sub-field of economics;

(iii) we may be badly informed about how influential the articles can be from a range of journals (it has become common, in my 30-year professional lifetime, to hear people focus on a tiny number of

\footnotetext{
1 I have been influenced by Bruce Charlton's and Peter Andras's CHARLTON AND ANDRAS [2008] view that we should evaluate whether the UK is producing revolutionary science and not merely normal, solid science. Bruce Charlton has pointed out to me that some non-revolutionary papers acquire high numbers of citations. He sees to me right. However, high citations numbers are presumably a necessary if not a sufficient condition, and I therefore feel the later exercise is potentially useful.

2 To be more exact, at the time of writing the paper actually ranks number 5 out of more than 20,000 articles in the Web of Science 'Economics' classification for 2009, but I think it is reasonable to neglect the four articles above it because they are made up of survey papers and highly specialized finance papers.
} 
journal 'labels' per se, and even sometimes to speak as though a publication in a place like the American Economic Review is an end in itself rather than mattering for its content or its contribution to human welfare);

(iv) we may be poorly informed about the latest flow of research and excessively influenced by out-of-date stock variables (such as, for example, the long-standing reputation of another department, or of a particular economist).

This article updates, and closely mirrors ${ }^{4}$, OSWALD [2010]. It follows a methodology that I hope objective observers could agree upon ex ante, namely, before they see the data on how they and their own department do. The proposed method is a simple one to implement. By its nature, any findings from it can be checked by others.

I collect data on the world's most-cited economics articles over the approximate period of the REF, namely, from 2008-2014. I then calculate the proportion of articles from the UK. My attempted aim, here, is to make operational the kind of $4^{*}$ concept encapsulated in the quote at the beginning of the paper. [Anticipating what is to come, for a journal such as the American Economic Review, for example, the later suggested method ultimately means that I take the 3\% most-cited AER articles from all countries and then, from within that already highly select group, work out the percentage of these influential articles that originated from a university in the United Kingdom.] 5

\footnotetext{
3 of course the Oxford Bulletin is not usually the home of the most-cited article: by definition the high impact-factor journals get more citations in large samples. I simply wish to illustrate the point that journal labels are an unreliable indicator of the quality of an individual paper.

4 I wish to warn the reader that some paragraphs and calculations literally repeat, of course now using the new data, the arguments in my early article.

5 Admittedly this is a highly 'non-linear' method. It puts a large weight on the very best articles in a scholarly discipline. But something of this type is required if we are trying to design a criterion for the upper $4^{*}$ grade in a system, such as the REF, where there are three categories of international excellence. It also recognizes the admittedly inegalitarian skewness in intellectual productivity -- a phenomenon sometimes known as Lotka's Law -- whereby a rather small proportion of articles or people produce the majority of the work of lasting impact. I include self-citations because there is a case for leaving them in and they make only a trivial difference in the case of highly-cited papers such as those covered here; I do not weight by the source of the citing journal; doing so would in my judgment be against the spirit of free competition among intellectual ideas. Nevertheless, I remain conscious of the difficulties and sociological influences pointed out by BORNMANN and DANIEL [2008].
} 
The paper's findings are relevant to the concerns of MACHIN and OSWALD [2000], FREY [2003], NEARY et al [2003], STARBUCK [2005], DREZE and ESTEVAN [2006] and CARDOSO et al [2008].

My suggested method can be used in other settings. The exercise might perhaps usefully be done for European research across a range of academic disciplines.

\section{The Method}

I use data from the ISI Web of Science, which is produced by Thomson. It is probably the most widely used source of citations data. Google Scholar and Scopus are possible alternatives.

Citations ${ }^{6}$ are taken here as a proxy for the objective quality of an article (measured with the benefit of hindsight). Such an approach is defensible but imperfect. I shall not here rehearse the possible difficulties.

The later calculations reveal that over the REF the UK produced some of the most-cited articles in the world in a number of important economics field journals. It has also been the source of some of the most influential articles in the AER, Review of Economic Studies, and Econometrica.

I take the journals listed by the Helpman Committee in the recent ESRC Benchmarking Report on Economics in the United Kingdom, HELPMAN et al [2008]. There is little dispute that these are important journals. There are 22 of them. They are divided into 9 general journals and 13 field journals. The journals are the American Economic Review, Economic Journal, Review of Economic Studies, Econometrica, International Economic Review, Review of

\footnotetext{
6 See work such as HAMERMESH et al [1982], OPPENHEIM [1995], HAMERMESH and SCHMIDT [2003], HAMERMESH and PFANN [2012], and GOODALL [2006, 2009], in which citations are treated as real signals. A particularly early and innovative paper, which remains unpublished, is SMART and WALDFOGEL [1996]. Some defence against possible peer review bias is provided by OSWALD and JALLES [2007]. However, citations are not free of error, and in the long run it may not be sensible to see citations as unambiguously valuable (the more that citations are emphasized, as in this article I would accept, the more that their signalling value will be eroded). HUDSON [2007] identifies some serendipitous influences on citations totals.
} 
Economics and Statistics, Journal of the European Economic Association, Journal of Political Economy, Quarterly Journal of Economics, Journal of Econometrics, Journal of Public Economics, Journal of Development Economics, Journal of Health Economics, Journal of Monetary Economics, Journal of International Economics, Journal of Finance, Rand Journal of Economics, Journal of Urban Economics, Journal of Labor Economics, Journal of Environmental Economics and Management, Journal of Law and Economics, and Journal of Economic Theory.

It would certainly be possible to object that a few significant journals are missing from these (the Journal of Financial Economics and the Journal of Economic History 7 , for example), but I adopt this list because it is the one chosen by Helpman and thus for this particular study helps avoid suggestions that I was consciously or unconsciously biased in my selection.

For each journal, I searched on articles published between January 2008 and December 2014. Thus I included an extra year of publications after the official end of the REF period (though this has no material effect on citations-ranking numbers). I used the rank-by-citations facility of the Web of Science to order these from the most-cited downwards. I then searched as carefully as possible by hand through the articles for the UK-based ones ${ }^{8}$. The problem with not doing this by hand is that any mechanical search on England will throw up articles that are not truly from England - such as those authored by Americans with an honorary affiliation to the CEPR in London. 9

\footnotetext{
7 I wanted to have an economic history journal, because I think that sub-field is particularly important. But over the period even the Journal of Economic History is comparatively little-cited. The marginal cites on the $10^{\text {th }}$ most-cited paper in JEH is 14 . So I decided, reluctantly, that I could not quite justify including this with the Helpman list. In passing, two high-impact journals, the Journal of Economic Literature and Journal of Economic Perspectives, are also omitted from the Helpman list -- presumably because they are collections of review articles. Two other omitted journals are the newish but increasingly important ones of the Journal of Economic Geography and Games and Economic Behaviour.

8 This is a tricky thing to do completely accurately (occasionally the addresses of authors can be hard to work out), and it is likely that small errors of counting remain, but it is too be hoped that they are randomly distributed across universities.

9 It is now believed that this error was made by Evidence Ltd in their work for the Helpman Report HELPMAN et al [2008], but the company has not provided me with enough information to judge its size.
} 
It is worth emphasising that there is evidence that early citations numbers to an article are a good indicator of long-run citations numbers. See, for example, ADAMS [2005]. In other words, if an article acquires few citations early on it is unusual -- of course there are occasional exceptions -- for it ever to acquire a high number.

Two caveats on the use of citations -- suggested to me by Bill Starbuck -might be added in passing. First, because Americans outnumber everyone else in terms of the numbers of academics and the amounts of money spent on journals, the particular views and judgments of Americans are likely to dominate the citations data. Insofar as there may be cultural differences between American and British of European researchers, American values then count for a lot. Second, methodological, abstract-theoretical and review articles receive more citations than do empirical articles. This is probably due to the use of review-theory articles as shorthand for "I am familiar with the literature".

The key data are set out in Table 1. It tells us the influential recent articles from UK economics and, perhaps even more interestingly, where they lie in a world-ranking of influence.

To try to adjust for the fact that some journals attract a particularly large quantity of good articles, I allow different journals to have different numbers of articles in the key table -- 50 for the American Economic Review, 20 for the Economic Journal, and so on. These cut-offs were chosen to try to be fair to the different journals, while maintaining the list of journals used in the last calculation of this sort (OSWALD 2010).

To give a sense of how selective the mechanism is, we are choosing in the case of the AER just the top 50 articles out of 1500 published articles over the period, namely, one article in thirty. This is an extraordinarily tough standard to set but it is designed to get at the principle of " $4^{*} \ldots$ a primary reference in its field". 
My method differs from, but I hope is complementary to, the work of VASILAKOS et al [2007].

To read Table 1, the procedure is the following ${ }^{10}$. Take the numbers in the top row as an example. These tell us that if we look at the 50 most-cited articles published by all countries in the American Economic Review over the 2008-2014 period then the UK was the source of 8 of these out of the 50. For a small country, this seems a substantial number. The UK ones were the $6^{\text {th }}$ most-cited article in the world, the $10^{\text {th }}$, and so on. Moreover, these four articles came, respectively, from LSE on the first, Nottingham on the second, UCL on the third, and LSE on the fourth. It can be seen from the table that the UK attained the top slot in the Economic Journal and the International Economic Review, and $2^{\text {nd }}$ in the Review of Economic Studies, Econometrica, and the Journal of Public Economics.

This is a substantial achievement for the United Kingdom. Nevertheless, although I do not report the full data, the UK numbers are far behind those for the (obviously much larger) United States.

These citations totals were collected at the end of 2014. They will, of course, increase through time.

10 Neil Shephard has previously suggested to me that ideally the individual papers should be normalized by their year of publication (because a publication earlier has had longer to build up cites than one published later). He is right, of course. The reason I do not do so here, and why I use a form of simple averaging, is that I am trying to assess UK economics rather than individual researchers' work. 


\section{Institutions' Contributions to the UK World-Leading Papers}

It seems of interest to look at which institutions contributed these 54 important articles ${ }^{11:}$

$\underline{\text { Web of Science Data }}$

LSE $\quad 18$ articles

Oxford $\quad 10$

UCL $\quad 6$

LBS $\quad 3$

Warwick 3

Nottingham 3

Cambridge 2

Durham 2

Essex 2

Imperial 2

R. Holloway 2

Southampton 2

and, interestingly, 6 other universities or centres contributed one article each. It should be noted that my measure here assigns full weight to a jointly authored article, so that a tri-authored Article $Y$ by economists from Universities A, B, C would see each of those universities credited above.

\section{Conclusions}

This paper is an attempt to design an objective way to assess the genuinely 'world-leading' research produced by a nation. Although its method is a general one, the paper illustrates the proposed approach by using information on the United Kingdom and on the subject of economics.

\footnotetext{
11 Hashem Pesaran has previously made the point to me that ideally we need to know where the important research was done -- rather than simply where the author is when credited in the journal. I would like to be able to do this. But it is not possible, at least for me, to adjust the data in this way.
} 
I examine data, for the UK's Research Excellence Framework period of 20082014 , on what might reasonably be described as the world's most influential economics articles. By using a consistent method, the numbers in this paper update those in OSWALD [2010] from the previous RAE period, so they allow comparison through time. The proposed approach is intellectually a general one; in principle, it could be applied to any other academic discipline, or to any country.

Following the Helpman report for the ESRC, I have concentrated on 22 wellknown economics journals. This is not because I view these as the only journals that matter. But it reduces possible objections that I chose the journals to obtain some desired result. I am conscious that, by the nature of the argument in this paper, I could throw the net wider.

On balance, I conclude that in economics the United Kingdom comes out fairly well on this criterion. Over the REF period, the UK produced $12 \%$ of the really important work. This compares with $10 \%$ last time in the RAE period. Among a set of 450 genuinely world-leading articles -- these are approximately the most-cited papers produced in the world over the period -- I find that the UK has been the source of 54 of them. A UK departmental ranking using this objective criterion looks similar to that generated by simple REF data. However, the dominance of the London School of Economics, for this particular era, has been striking. 12 Over the REF period it produced approximately one third of the UK's genuinely world-leading research in the field of economics.

12 Such things can change rapidly, of course. My own department has since hired senior economists who contributed 5 articles to the list of 450 world-leading articles even though those articles were at the time (and thus are in Table 1) credited to different universities. Other universities may have done something equivalent. 


\section{$\underline{\text { References }}$}

ADAMS, JONATHAN. (2005), Early citation counts correlate with accumulated impact. Scientometrics, 63 (3): 567-581.

BORNMANN, LUTI, AND DANIEL, HANS-DIETER. (2008), What do citation counts measure? A review of studies on citing behavior. Journal of Documentation, 64(1): 45-80.

CARDOSO, ANA RUTE, GUIMARAES, PAULO, AND ZIMMERMAN, KLAUS F. (2008), Comparing the early research performance of $\mathrm{PhD}$ graduates in labor economics in Europe and the USA. IZA Discussion Paper, \#3898.

CHARLTON, BRUCE, AND ANDRAS, PETER. (2008), Down-shifting among top UK scientists? The decline of revolutionary science and the rise of normal science. Medical Hypotheses, 70 (3): 465-472.

DREZE, JACQUES H. AND ESTEVAN, FERNANDA. (2006), Research and higher education in economics: Can we deliver the Lisbon objectives? Journal of the European Economic Association, 5 (2): 271-304.

FREY, BRUNO S. (2003), Publishing as prostitution? Choosing between one's own ideas and academic success. Public Choice, 116: 205-223.

GOODALL, AMANDA H. (2006), Should research universities be led by top researchers, and are they? A citations analysis. Journal of Documentation, 62 (3): 388-411.

GOODALL, AMANDA H. (2009), Socrates in the boardroom: Why research universities should be led by top scholars. Princeton University Press.

HAMERMESH, DANIEL S., JOHNSON, GEORGE E. AND WEISBROD, BURTON A. (1982), Scholarship, citations and salaries: Economic rewards in economics. Southern Economic Journal, 49(2): 472-481.

HAMERMESH, DANIEL S. AND SCHMIDT, PETER. (2003), The determinants of Econometric Society fellows elections. Econometrica, 71: 399-407.

HAMERMESH, DANIEL S. AND PFANN, GERARD. (2012), Markets for reputation: The roles of quantity and quality in academe. Economic Inquiry, 50: 1-16.

HELPMAN, ELHANAN et al. (2008) ESRC International benchmarking study of UK economics. ESRC. Swindon.

HUDSON, JOHN. (2007), Be known by the company you keep: Citations - quality or chance? Scientometrics, 71(2): 231-238.

MACHIN, STEPHEN AND OSWALD, ANDREW J. (2000), UK economics and the future supply of academic economists. Economic Journal, 110: F334-F349.

NEARY, J. PETER, MIRRLEES, JAMES A. AND TIROLE, JEAN. (2003), Evaluating economics research in Europe: An introduction. Journal of the European Economic Assocation. 2003, 1: 1239-1249.

OPPENHEIM, CHARLES. (1995), The correlation between citation counts and the 1992 Research Assessment Exercise Ratings for British library and information science university departments. Journal of Documentation, 51: 18-27. 
OSWALD, ANDREW J. (2007), An examination of the reliability of prestigious scholarly journals: Evidence and implications for decision-makers. Economica, 74: 21-31.

OSWALD, ANDREW J. (2010), A suggested method for the measurement of world-leading research (illustrated with data on economics). Scientometrics, 84: 99-113.

OSWALD, ANDREW J. AND JALLES, JOAO. (2007), Unbiased peer review and the averaging fallacy. Working paper, Warwick University.

REGIBEAU, PIERRE AND ROCKETT KATHERINE. (2014), A tale of two metrics: Research assessment versus recognized excellence. Essex University Discussion Paper, Number 757.

ROODMAN, DAVID. (2009), A note on the theme of too many instruments. Oxford Bulletin of Economics and Statistics, 71: 135-158.

SGROI, DANIEL AND OSWALD ANDREW J. (2013), How should peer-review panels behave? Economic Journal, 123: F255-F278.

SMART, SCOTT AND WALDFOGEL, JOEL. (1996), A citation-based test for discrimination at economics and finance journals. Working paper, Indiana University, and NBER paper 5460. January.

STARBUCK, WILLIAM H. (2005), How much better are the most prestigious journals? The statistics of academic publication. Organization Science, 16: 180-200.

VASILAKOS, NICHOLAS, LANOT, GAUTHIER, AND WORRAL, TIM. (2007), Evaluating the performance of UK research in economics. Report sponsored by the Royal Economic Society. 


\section{TABLE 1}

\section{How Did UK Economics Do Over the Period 2008-14 if J udged Against the Most-Cited Articles Produced Around the World?}

Notes to reading this table: the top row means that if we look at the 50 most-cited articles published by all countries in the American Economic Review over the 08-15 period, then the UK was the source of the $6^{\text {th }}$ most-cited article, the $10^{\text {th }}$ most cited, and so on. If an article is marked, for example, LSE+UCL it means that in the list of authors there was an author from the London School of Economics and one from University College London.

Different journals are assigned different values of $X$, because some journals here are intrinsically more cited than others. The lower cut-off levels of cites are reported in square brackets in the first column. Hence the number 65 after AER means that the $50^{\text {th }}$ most-cited paper in the American Economic Review attained 65 cites.

The citations totals were collected in January of 2015.

\begin{tabular}{|c|c|c|c|c|}
\hline $\begin{array}{l}\text { J ournal } \\
\text { [lower cut-off } \\
\text { marginal \# cites] }\end{array}$ & $\begin{array}{l}\text { Criterion: } \\
\text { Appearing } \\
\text { among the } X \\
\text { most-cited } \\
\text { articles in that } \\
\text { journal where } X \\
\text { here is the top: }\end{array}$ & $\begin{array}{l}\text { Were there } \\
\text { any UK } \\
\text { papers } \\
\text { within } \\
\text { these top X } \\
\text { articles? }\end{array}$ & $\begin{array}{l}\text { Their } \\
\text { positions } \\
\text { in the } \\
\text { world } \\
\text { rank of } \\
\text { these } \\
\text { most-cited } \\
X\end{array}$ & $\begin{array}{c}\text { Which UK } \\
\text { institutions were } \\
\text { the source of these } \\
\text { highly-ranked } \\
\text { papers? }\end{array}$ \\
\hline AER [65] & 50 & Yes & $\begin{array}{l}6^{\text {th }} ; 10^{\text {th }} ; \\
25^{\text {th }} ; 34^{\text {th }} ; \\
35^{\text {th }} ; 43^{\text {rd }} \\
44^{\text {th }} ; 46 \text { th }\end{array}$ & $\begin{array}{l}\text { LSE; Nottingham; UCL; } \\
\text { LSE; LSE; LSE; } \\
\text { Nottingham; LSE }\end{array}$ \\
\hline EJ [45] & 20 & Yes & $\begin{array}{l}1 \mathrm{st} ; 3^{\text {rd }} ; 5^{\text {th }} \\
7^{\text {th }} ; 18 \text { th }\end{array}$ & $\begin{array}{c}\text { Brunel; Imperial } \\
\text { College London; } \\
\text { Warwick; Birmingham; } \\
\text { Bristol+Oxford }\end{array}$ \\
\hline REStud [49] & 20 & Yes & $\begin{array}{l}2^{\text {nd }} ; 6^{\text {th }} ; 16^{\text {th }} ; \\
19^{\text {th }} ; 20 \text { th }\end{array}$ & $\begin{array}{c}\text { Royal Holloway London; } \\
\text { Essex+Cambridge; } \\
\text { Oxford; LSE; } \\
\text { Aberdeen+LSE }\end{array}$ \\
\hline Econometrica [32] & 50 & Yes & $\begin{array}{l}2^{\text {nd }} ; 3^{\text {rd }} ; 8^{\text {th }} ; \\
12^{\text {th }} ; 23^{\text {rd. }} ; \\
26^{\text {th }} ; 31^{\text {st }} ; \\
34^{\text {th }} ; 38 \text { th }\end{array}$ & $\begin{array}{c}\text { Oxford; Durham; LSE; } \\
\text { LSE; UCL+LSE; LSE; } \\
\text { LSE; York; } \\
\text { Southampton }\end{array}$ \\
\hline IER [27] & 10 & Yes & 1st; $6^{\text {th }} ; 9$ th & $\begin{array}{c}\text { Nottingham; } \\
\text { Southampton; Durham }\end{array}$ \\
\hline REStats [44] & 20 & Yes & 8th & $\mathrm{UCL}$ \\
\hline JEEA [51] & 10 & Yes & 7th & LSE \\
\hline JPE [26] & 40 & No & & \\
\hline QJE [49] & 50 & Yes & $\begin{array}{l}8^{\text {th }} ; 17^{\text {th }} ; \\
18^{\text {th }} ; 34 \text { th }\end{array}$ & $\begin{array}{c}\text { LBS; Stirling; } \\
\text { Edinburgh+LSE; UCL }\end{array}$ \\
\hline JEconometrics [40] & 20 & Yes & $15^{\text {th }} ; 19$ th & Oxford; Cambridge \\
\hline JPubEcon [54] & 10 & Yes & 2 nd; $3^{\text {rd }} ; 4$ th & $\begin{array}{c}\text { Warwick+London; } \\
\text { Oxford+Warwick; } \\
\text { Oxford }\end{array}$ \\
\hline JDevEcon [58] & 10 & Yes & 7th & Imperial London \\
\hline JHealthEcon [62] & 10 & No & & \\
\hline JMonetaryEcon [51] & 10 & No & & \\
\hline JIntEcon [41] & 10 & Yes & 9th & Oxford \\
\hline JFinance [50] & 50 & Yes & $13^{\text {th }} ; 33 r d$ & LBS+Oxford; LBS \\
\hline Rand Journal [31] & 10 & Yes & $4^{\text {th }} ; 7$ th & LSE; UCL+Oxford \\
\hline JUrbanEcon [55] & 10 & No & & \\
\hline JOLE [31] & 10 & Yes & $\begin{array}{c}3^{\text {rd }} ; 5^{\text {th }} ; 6^{\text {th }} \\
9 \text { th }\end{array}$ & $\begin{array}{l}\text { LSE; LSE; Royal } \\
\text { Holloway; UCL }\end{array}$ \\
\hline JEnvEcon\&Man[44] & 10 & Yes & 5th & Queens Belfast+UEA \\
\hline JLaw\&Econ [18] & 10 & No & & \\
\hline JET [31] & 10 & Yes & $5^{\text {th }} ; 7$ th & Oxford; Essex \\
\hline
\end{tabular}




\begin{tabular}{|c|l|l|l|l|}
\hline $\begin{array}{c}\text { Total \# world-leading } \\
\text { papers from the UK }\end{array}$ & & 54 & \\
\hline
\end{tabular}

Note: Because over the period the JPE declined so markedly in marginal citations, and the EJ rose so markedly, I have slightly altered the (previous OSWALD 2010) numbers of articles counted to be respectively 40 articles from the JPE and 20 articles from the EJ. This alteration makes essentially no difference to the UK's ranking.

Changing the cut-off on the American Economic Review instead to 80 articles would alter its marginal citations to 49. Doing this would produce two more UK articles, one from LSE and one from Oxford, and would not materially influence the conclusions of this paper.

However, broadly, I have chosen not to fine-tune the other journal cut-offs for the reason that it seems valuable to maintain consistency and allow comparison with the UK previous RAE 2008 results as reported OSWALD 2010. 